\title{
Certum atque Confessum: Lorenzo Valla on the Forensics of Certainty
}

\begin{abstract}
Im Zentrum von Vallas Umgestaltung der Dialektik als rhetorischer Methode steht ein neues Verständnis von certum, das aus Quintilians Institutio oratoria stammt. Diesem Verständnis zufolge ist Gewissheit in dem begründet, was allgemein akzeptiert wird, nicht in dem, was wahr ist. Damit trennt Valla certum und verum. In den Dialecticae disputationes stellt er Dialektik nicht als eine logische oder philosophische Methode zum Beweis von Wahrheiten dar, sondern als Praxis Geständnisse herbeizuführen und als juristische Produktion konsensueller Gewissheiten. Auch in anderen Werken, etwa den Elegantiae und seinem Kommentar zu Quintilians Institutio, verbindet er durchweg certum mit Konsens, insbesondere Konsens im Sinne der rhetorischen Strategie der status-Theorie.
\end{abstract}

Keywords: Valla, Quintilian, argumentation, proof, certainty, dialectic

arious studies have illustrated Lorenzo Valla's extensive use of rhetorical concepts and texts in his critical approach to scholasticism, so it is by this point uncontroversial to argue that this pugnacious humanist engaged in the "rhetoricization of dialectic." 1 Also uncontroversial is Valla's particular reliance

I thank the editors and readers at Rhetorica for their careful commentary. I am particularly grateful to Kathy Eden for her guidance on this project from its earliest stages of research and also to Lodi Nauta for his insightful comments on a version of this paper delivered at the Renaissance Society of America's 2017 meeting in Chicago.

${ }^{1}$ For a discussion of Valla's interest in the rhetorical texts of antiquity as guides for the acquisition of knowledge, see S. Camporeale, "Lorenzo Valla: The Transcending of Philosophy through Rhetoric," Romance Notes 30:3 (1990): 269-284; L. Janik, "Lorenzo

Rhetorica, Vol. XXXVI, Issue 3, pp. 244-268. ISSN: 0734-8584, electronic ISSN: 15338541. (C) 2018 by The International Society for the History of Rhetoric. All rights reserved. Please direct all requests for permission to photocopy or reproduce article content through the University of California Press's Reprints and Permissions web page, http:/ /www. ucpress.edu/journals.php?p=reprints. DOI: https://doi.org/10.1525/rh.2018.36.3.244 
on Quintilian for these reformations, both as a matter of a longstanding preference for this ancient schoolmaster's thought as well as a matter of the history of the humanist re-discovery of the texts of antiquity. ${ }^{2}$ For even if the famous papal secretary-cum-book hunter Poggio Bracciolini recovered a complete manuscript of Quintilian's Institutio oratoria at the monastery of St. Gall in 1416, Valla rather than Poggio himself took up the task of editing the damaged text later in the century. ${ }^{3}$ It is not surprising, then, that Quintilian's Institutio, within arm's reach, should exert a special influence on Valla, and even an influence in works that might seem outside the obvious applicability of an oratorical textbook.

Rather than argue yet again that Quintilian was influential in Valla's thinking or even more particularly in his efforts to "rhetoricize" dialectic, I turn in this discussion to the vocabulary that Valla uses in these efforts and how this vocabulary stems from his interactions with Quintilian's writings. More exactly, Valla relies on an ancient understanding of certainty - the quality of being certum - in his reorientation of dialectic around the strategies and terminology of the rhetorical tradition. This ancient version of certainty, which signifies a kind of consensus rather than the scientific objectivity denoted by the modern term of the same name, traces its rhetorical formulation to the writings of Quintilian. By turning to Valla's manuscript edition of the Institutio and his marginal annotations, one sees how this humanist author was

Valla: The Primacy of Rhetoric and the De-Moralization of History," History and Theory 12:4 (1973): 389-404; and L. Jardine, "Lorenzo Valla and the Intellectual Origins of Humanist Dialectic," Journal of the History of Philosophy 15:2 (1977): 143-164. For a discussion of Valla's preference for rhetoric over dialectic, especially in the context of later humanist thinking, see L. Nauta, "Anti-Essentialism and the Rhetoricization of Knowledge: Mario Nizolio's Humanist Attack on Universals," Renaissance Quarterly 65:1 (2012): 31-66.

${ }^{2}$ For an account of Valla's preference for Quintilian over Cicero and the assessment of Quintilian among some of his humanist contemporaries, see C. J. Classen, "Quintilian and the Revival of Learning in Italy," Humanistica Lovaniensia 43 (1994): 77-98; and L. Cesarini Martinelli, "Le Postille di Lorenzo Valla all' "Institutio oratoria" di Quintiliano," in Ottavio Besomi and Mariangela Regoliosi, eds., Lorenzo Valla e l'Umanesimo Italiano (Padova: Antenore, 1986), 21-50. In his letters, too, Valla writes that he is "the man who composed a Commentary on Cicero and Quintilian in which I exalted Quintilian above Cicero, Demosthenes, and Homer himself" (L. Valla, Correspondence, ed. and trans. B. Cook (Cambridge, MA: Harvard University Press, 2013), 110).

${ }^{3}$ Poggio, too, explains in a letter to Guarinus Veronensis that Quintilian "seems in my judgment to be perfect in both the highest theory and the most distinguished practice of oratory. From this man alone we could learn the perfect method of public speaking, even if we did not have Cicero, the father of Roman oratory" (P. Gordon, Two Renaissance Book Hunters: The Letters of Poggius Bracciolini to Nicolaus de Niccolis (New York: Columbia University Press, 1991), 193-194). 
eager to follow his ancient predecessor in understanding the meaning of certum through the lens of forensic persuasion rather than philosophical truth as such. This rhetorical orientation of certainty persists in Valla's Elegantiae, too, and throughout his Dialecticae disputationes, where Valla leverages Quintilian's peculiar understanding of certainty in his efforts to reform the modal logic of scholasticism. By concentrating on Valla's deliberate use of this term, this study aims to reinforce the scholarly understanding of Valla's rhetorical frame and to provide a historical antecedent to his writings that insist upon the separation of truth and certainty. ${ }^{4}$

This lexical study proceeds in three parts. First, Valla's marginal annotations in his manuscript edition of the Institutio reveal how Valla adopts Quintilian's understanding that certum denotes a kind of consensus, and in particular one of a legal nature. Second, this notion of certainty as a kind of forensic agreement reappears in Valla's Dialecticae disputationes, where the association of certum with courtroom confession cements this concept's rhetorical orientation and illustrates its function in reimagining dialectic as a process of crafting agreement rather than one of purely logical proof. Finally, Valla's discussions of the conventional basis of the lawdiscussions that stretch across several writings-illustrate his view of the complex interactions between the veritas of rational discourse and the certitudo of rhetorical persuasion.

\section{Quintilian as a Source of Certainty}

According to the notes on the final page of his manuscript, Valla likely completed editing the text of the Institutio in December of 1444 . $^{5}$ Although Valla had access to substantial portions of Quintilian's text before his editorial work on Poggio's discovered manuscript, this later, complete edition is remarkable for Valla's extensive marginal

\footnotetext{
${ }^{4}$ For a helpful treatment of certainty in Valla's Dialecticae disputationes and Quintilian's influence on Valla's thinking, see L. Nauta, In Defense of Common Sense: Lorenzo Valla's Humanist Critique of Scholastic Philosophy (Cambridge, MA: Harvard University Press, 2009), 233-234. I expand here on Nauta's account of "Valla's central idea [that] all our speaking and arguing should be ruled by custom and convention," and I argue furthermore that Valla's debt to Quintilian manifests in a specialized set of vocabulary-including certum and associated terms-in many of his writings, not only in the Disputationes.

${ }^{5}$ Laurentius Valla hunc codicem sibi emendavit ipse anno millesimo quadringentesimo quadragesimo quarto mense decembri die nono (L. Cesarini Martinelli and A. Perosa, Le Postille all'“Institutio Oratoria" di Quintiliano: Edizione Critica (Padova: Antenore, 1996), xii).
} 
commentary, notes that provide some access to Valla's thinking about this influential ancient source. ${ }^{6}$ As with the rest of Valla's edition, the fifth book of Quintilian's text is brimming with marginal notes, and alongside Book 5's technical discussion of the varieties of arguments-enthymemes, epicheiremes, entechnical proofs, and so forth-these explanatory annotations are especially useful. In this book, too, we find annotations that reveal the humanist's understanding of certainty, of what it means to be certum.

Before directing my attention to Valla's notes themselves, however, I turn first to one key passage of Quintilian's text where the ancient teacher of rhetoric considers the meaning of certum within a larger discussion about the "nature of all arguments" (natura omnium argumentorum, 5.10.8). In a succinct definition of argumentation, Quintilian explains that "reasoning lends credence to matters of doubt (dubia) through things which are certain (certa)," and since he has placed "certainty" at the very heart of his notion of what arguments do, Quintilian specifies shortly thereafter how one ought to understand this central term ${ }^{7}$ :

Now we regard as certa things perceived by the senses, for example what we see or hear (signs come under this head); things about which common opinion is unanimous: the existence of gods, the duty of respecting parents; provisions of laws; what has been accepted as moral custom, if not in the belief of all mankind, at least in that of a city or nation where the case is being pleaded-many matters of right, for example, involve custom rather than laws; whatever is agreed upon between both parties; whatever has been proved; lastly, whatever is not contradicted by our opponent. ${ }^{8}$

\footnotetext{
${ }^{6}$ Portions of Quintilian's text were available before Poggio's discovery, including the passages from Books 2, 3, and 5 discussed in this article. For a history of manuscripts of Quintilian's text, see M. Winterbottom, "Fifteenth-Century Manuscripts of Quintilian," The Classical Quarterly (New Series) 17 (1967): 339-369. The manuscript of the Institutio was well regarded not merely for its textual emendations but also for Valla's marginal notes: Winterbottom explains that "the name and fame of Lorenzo Valla gave his manuscript a large and swift progeny" and lists a selection of later editions that emerged from Valla's editorial work (p. 361-363). In fact, Valla's notes on the first two books of the Institutio were included in a Venetian printed edition of Quintilian's work in 1494, decades after Valla's death (J. E. Sandys, A History of Classical Scholarship, 3 vols. (Cambridge, UK: Cambridge University Press, 1908), 2:67).

${ }^{7}$ Ratio per ea quae certa sunt fidem dubiis adferens: quae natura est omnium argumentorum, 5.10.8. Translations of Quintilian's text are adapted from The Orator's Education, ed. and trans. D. A. Russell, 5 vols. (Cambridge, MA: Harvard University Press, 2001).

${ }^{8}$ Pro certis autem habemus primum quae sensibus percipiuntur, ut quae videmus audimus, qualia sunt signa, deinde ea in quae communi opinione consensum est: "deos esse," "praestandam pietatem parentibus," praeterea quae legibus cauta sunt, quae persuasione
} 
This litany of certainties can be divided into three categories. First, Quintilian turns his attention to matters of sense perception, "what we see or hear," a definition that likely stems from the idea of "discerning" represented by the Latin verb cernere. Its past participle cretum is merely one transposition away from the adjective under discussion here, and ancient authors seem to acknowledge this etymological connection in several works. ${ }^{9}$ As a second category-and surely secondary in importance-Quintilian briefly points to matters that have been previously proven, quid probatum est. But third and most emphatically, Quintilian defines "certainty" as matters of agreement, whether most broadly as beliefs for which "common opinion is unanimous," or in the more limited case of city-wide laws or even the particular agreements between two parties in a courtroom. Indeed, Quintilian's list of certa is largely framed in the concerns and terminology of forensic rhetoric: inter utramque partem and adversarius both remind readers that the arguments and certainties under discussion are legal in their nature. But even so, we might summarize Quintilian's understanding of certum not as any particular law or custom but rather as the more general concept of consensum, a word he himself uses in this catalog.

This understanding of certum as consensus or agreement seems to capture Valla's attention if his marginal annotation can be seen as even a rough indication of his understanding of the original text. Alongside Quintilian's discussion of various certa, Valla inserts a paragraph from the Justinian Digest, where the imperial jurist Julianus draws a distinction between laws that are formally enacted through votes and those that are enacted by a people's "very deeds and actions"10:

etiam si non omnium hominum, eius tamen civitatis aut gentis in qua res agitur in mores recepta sunt, ut pleraque in iure non legibus sed moribus constant: si quid inter utramque partem convenit, si quid probatum est, denique cuicumque adversarius non contradicit, 5.10.12-13.

${ }^{9}$ One might consider Ennius' well-known fragment amicus certus in re incerta cernitur (351, Jocelyn) as an early example of wordplay surrounding cernere and certum. For further examples of certum as a word rooted in concerns of sense perception, see TLL vol. III 915, 45sqq. In Leviathan (2.27), too, Thomas Hobbes explains that the Latin noun crimen is derived from "Cerno, which signifies to perceive," and that such a crimen denotes "onely such sinnes, as may be made appear before a Judge . . . [and] not meer Intentions" (ed. Noel Malcolm (Oxford: Clarendon Press, 2012), 2:454).

${ }^{10}$ Cesarini Martinelli and Perosa write that "the discipline most persistently investigated in the marginal comments of Quintilian in each case is the law: Valla has stripped the Corpus iuris (and the Sententiae of Paulus) looking for evidence pertaining to the legal situations described by the orator" (Le Postille all" Institutio Oratoria" di Quintiliano, cited in n. 5 above, p. lxxxi). For a discussion of Valla's approach to study of the law and his place among other Renaissance jurists, see D. Kelley, "The Rise of Legal History in the Renaissance," History and Theory 9:2 (1970): 174-194. 
Long-standing custom (consuetudo) is observed in the place of law with good reason, and this is the law which is said to be settled by customs (moribus constitutum). For as these laws in particular restrain us for no other reason than because they are accepted by the judgment of the public, those things which the populace approved without any written law justly restrain all men: for what difference is there whether the populace declares its will by vote or by its very deeds and actions? It is understood most correctly, therefore, that laws may be abolished not only by the vote of the proposer of a law but also by the silent agreement of all people through disuse (tacito consensu omnium per desuetudinem). ${ }^{11}$

Notably, Valla does not point to an ancient discussion of sense perception as a helpful comparison or etymological clarification of Quintilian's definition. Rather, just as Quintilian himself points to customs and laws as examples of certainties, Valla preserves this forensic orientation in juxtaposing the notion of certum with the consuetudo and "very deeds and actions" of a community-that is, Valla associates common practices rather than "discerning" with certainty. This emphasis on consuetudo extends to the end of Valla's citation, too, where Julianus sees that laws can be overturned "by the silent agreement (tacito consensu) of all through disuse (desuetudo)," where such "disuse" emerges through the common beliefs or practices of the many. ${ }^{12}$ And perhaps even more notable than Valla's drawing out the theme of customary law is his repeated citation of words that include the Latin prefix con-: consuetudo, constitutum, consensus. By citing

\footnotetext{
${ }^{11}$ Inveterata consuetudo pro lege non immerito custoditur, et hoc est ius quod dicitur moribus constitutum. Nam cum ipse leges nulla alia ex causa [nos teneant,] quam quod iudicio populi recepte sunt, merito et ea, que sine ullo scripto populus [probavit], tenebunt omnes: nam quid interest utrum suffragio populus voluntatem suam declaret an rebus ipsis et factis? Quare rectissime et illud receptum est, ut leges non solum suffragio legis latoris, sed etiam tacito consensu omnium per desuetudinem abrogentur, 1, 3, 32, 1. Valla's marginal note does not include nos teneant after causa, but modern editions of the Digest include these two words. I have changed probabit to the perfect tense verb that appears in Julianus' text. Cesarini Martinelli and Perosa do not comment on these textual differences in their edition of Valla's marginal notes (cited in n. 5 above, p. 105).

${ }^{12}$ For Valla's link between utor and consuetudo, see his discussion at Elegantiae 5.5. Text of the Elegantiae and section numbers are taken from De linguae latinae elegantia, ed. S. L. Moreda, 2 vols. (Cáceres: Universidad de Extremadura, 1999). Unless noted otherwise, the numbering scheme of Moreda's critical edition matches that provided in the more widely available Opera omnia, ed. E. Garin, 2 vols. (Torino: Bottega d'Erasmo, 1962). For Valla's debt to Quintilian for his understanding of consuetudo, see M. J. H. Pareja "Quintiliano en las Elegancias de Lorenzo Valla," in T. Albaladejo, E. del Río, J. A. Caballero, eds., Quintiliano, historia y actualidad de la retórica: actas del Congreso Quintiliano (Calahorra: Instituto de Estudios Riojanos, 1998), 1363-1372.
} 
an ancient text that highlights Quintilian's own allusion to consensus and that draws out several other words that denote a "togetherness" of some kind or another, Valla underscores the role of agreement in the Institutio's original discussion. Both as a matter of subject-the customary habits of a group of people - and as a matter of lexical patterns, then, Valla suggests that he follows Quintilian in understanding certainty as a brand of agreement, and principally one of a legal orientation.

One sees in Valla's other writings, too, how this humanist reformer understands the concept of certainty with reference to the writings of Quintilian and how he maintains the association of certainty and consensus, even outside the immediate context of the Institutio's rhetorical interests. One example of this association can be found in Valla's most direct philological study of classical Latin vocabulary, his influential De linguae latinae elegantia (or Elegantiae), a 1441 handbook of language and style that aims to return to those exemplary authors of antiquity who were the "most devoted to speaking well."13 As an admirer of the prose of Cicero and especially Quintilian, Valla wrote these six volumes of learned stylistic recommendations to mitigate what he viewed as a decline and corruption of the purity of the Latin tongue. ${ }^{14}$

Valla treats a variety of words and phrases in the Elegantiae, where he prescribes correct sense and syntax usually by referencing model sentences from classical sources, and following this strategy, Valla looks to Quintilian to clarify the meaning of the phrase certum est:

\footnotetext{
${ }^{13}$ Valla includes among those "most devoted to speaking well" (bene loquendi studiosissimi) not only orators and jurists but also philosophers and writers (1.pr). For a description of the methods of the Elegantiae, especially as the work compares with grammatical works of antiquity and his own era, see D. Marsh "Grammar, Method, and Polemic in Lorenzo Valla's Elegantiae," Rinascimento 19 (1979), 91-116. For a more recent study on the predecessors and influence of the Elegantiae, see A. Moss, Renaissance Truth and the Latin Language Turn (Oxford: Oxford University Press, 2003), 35-63. For an account of Valla's philological methods outside this lexicographical work, see S. Camporeale, "Lorenzo Valla's Oratio on the Pseudo-Donation of Constantine: Dissent and Innovation in Early Renaissance Humanism," Journal of the History of Ideas 57:1 (1996): 9-26. For studies of the novelty and influence of Valla's Elegantiae, see W. K. Percival, Studies in Renaissance Grammar (Burlington: Ashgate, 2004), 75. Translations of Valla's Elegantiae are my own.

${ }^{14}$ For Valla, the decrepitude of the Latin language mirrors the decrepitude of the city of Rome itself: "Everything has been overthrown, everything has been burned down, everthing has been ruined, so that hardly the Capitoline hill remains. And accordingly, for many centuries, not only has no one spoken Latin, but no one has even understood how to read it" (Omnia everta, incensa, diruta, ut vix Capitolina supersit arx. Siquidem multi iam saeculis non modo Latine nemo locutus est, sed ne Latina quidem legens intellexit, 1.pr).
} 
certum est is not just understood as "it is obvious" (manifestum est), as Quintilian does here: "Truly, it is certum that there is a law that one may kill an adulterer." But it is also understood as "it is carefully considered" (deliberatum est) or "it is settled" (constitutum est). In the second case, a dative with an infinitive is usually attached to the phrase, as in "it is certum for me to go into Spain." Sometimes the dative is merely implied, as is the case in Vergil: "it is certum that it is preferable to suffer in the forest, among the dens of beasts" ... that is, it is certum to me. ${ }^{15}$

Valla advances two primary understandings of this adjective. First, he links what is certain to what is "obvious" or "manifest" (manifestum), quickly turning to the authority of Quintilian as a source for this first definition. One might also see the first position of manifestum in Valla's explanation as a sign of his awareness of this Latin adjective's etymological origins in the vocabulary of perception, a word history that Quintilian himself foregrounds in his discussion of certainty in the Institutio. ${ }^{16}$ But the quality of being "manifest" figures prominently in legal texts as well, and Valla's swift turn to his preferred ancient source of rhetorical theory immediately grounds his investigation of manifestum in the world of forensic strategy rather than mere "discerning." ${ }^{\prime 17}$ Even if Valla had Book 5 of the Institutio and its detailed investigation of certainty at his fingertips, in fact, he nevertheless eschews this more direct treatment of certum in the Elegantiae and instead turns to an earlier passage of Quintilian's handbook. ${ }^{18}$ In his lexicographical study here, Valla cites Book 3 of the Institutio and its discussion of status theory, and in this context of rhetorical invention, not in the more explicit discussion of certainty two books later, do we find the

${ }^{15}$ certum est non modo accipitur pro manifestum est, ut Quintilianus: Nempe legem esse certum est; sed etiam pro deliberatum et constitutum est. In quo secundo plerumque adiungitur dativus cum infinitivo; ut, certum est mihi ire in Hispaniam. Nonnumquam datious subintelligitur, ut apud Vergilium: Certum est in sylvis, inter spelaea ferarum malle pati . . . Id est mihi, 5.27.

${ }^{16}$ Several Latin authors use manifestum in this sense of "visible" or "conspicuous," (OLD manifestus 4, 5, 6 and TLL vol. VIII 308, 39sqq.). Compare Quintilian's quae sensibus percipiuntur, 5.10.12.

${ }^{17}$ Manifestum was originally relevant to evidence in criminal cases, and appearances of manifestum in Plautus often describe those who are caught red-handed. For a number of examples of this understanding of the adjective in its criminal orientation, see TLL vol. VIII 307, 84sqq. and VIII 310, 8sq. For a discussion of the importance of forensic language to Roman comedic texts more generally, see A. Scafuro, The Forensic Stage: Settling Disputes in Graeco-Roman New Comedy (Cambridge, UK: Cambridge University Press, 1997), 25-67.

${ }^{18}$ Valla had access to incomplete manuscripts of the Institutio in 1441, the year he completed writing his Elegantiae, and the tenth chapter of Book 5 was likely available to him before Poggio's discovery in 1416 (Winterbottom, "Fifteenth-Century Manuscripts of Quintilian," cited in n. 6 above, p. 339). 
Elegantiae's quotation: "it is certum that there is a law that one may kill an adulterer." ${ }^{19}$

Orators, so Quintilian recommends in this earlier book, should refine the issue of their legal disputes by turning to the triad of questions at the heart of this Hellenistic rhetorical framework: whether something happened, what happened, and what kind of thing it was. ${ }^{20}$ As part of Book 3's long survey of the components of status theory, its various formulations, and its several practitioners, Quintilian provides as a hypothetical case of its usefulness the example later referenced in Valla's Elegantiae. In this scenario, a man accused of murder may defend himself by arguing that the murder victim was an adulterer, for Quintilian reminds his readers that it is "certain" that the law permits one to kill such a criminal:

Let us suppose the charge made by the accuser is "You killed the man." If the defendant denies it, it is he who produces the issue. But suppose he admits (confitetur) the fact, but says the adulterer was justifiably killed by him. (Truly, it is certum that there is a law that one may kill an adulterer.) Unless the accuser makes some reply, there is no case. ${ }^{21}$

While the accused admits what he has done-he agrees that he has killed another man-he denies the action was unjustified on account of the victim's adulterous behavior. In other words, while the two parties of this case provide the same answers to the first two status questions of whether something happened and what that something was, they disagree on the answer to the third regarding the circumstances surrounding the crime. What the prosecution calls cold-blooded murder,

\footnotetext{
${ }^{19}$ Status theory is a rhetorical framework where parties in a forensic dispute come to "a standing still" (that is, a status) in their arguments. For a brief study of the technique of status theory (also called stasis theory), see O. A. L. Dieter, "Stasis," Speech Monographs 17 (1950): 345-369. For a more recent account of status theory especially as it figures in the educational program of Quintilian's text, see E. Fantham, Roman Readings: Roman Response to Greek Literature from Plautus to Statius and Quintilian (Berlin: De Gruyter, 2011): 320-330. For a history of the development of status theory, see R. Nadeau, "Classical Systems of Stases in Greek: Hermagoras to Hermogenes," Greek, Roman, and Byzantine Studies 2 (1959), 52-71.

${ }^{20}$ For Hermagoras' original formulation of four status questions including the final question of "objection," see Nadeau, "Classical Systems of Stases in Greek: Hermagoras to Hermogenes," cited in n. 19 above, p. 53-54. Nadeau also writes that later Latin authors, including Cicero and Quintilian, consider the three questions listed here to be sufficient (p. 54).

${ }^{21}$ Sit enim accusatoris intentio: 'hominem occidisti'; si negat reus, faciet statum qui negat. Quid si confitetur, sed iure a se adulterum dicit occisum (nempe legem esse certum est quae permittat)? Nisi aliquid accusator respondet, nulla lis est, 3.6.17. In the Elegantiae, Valla omits the relative clause quae permittit in Quintilian's parenthetical statement.
} 
the defendant calls a justifiable and even legally permissible homicide. Quintilian posits that since it is certum that the law allows one to kill adulterers, there can be no disagreement about whether the defendant acted within his legal rights if his claims about infidelity are correct. But "if the prosecutor says, 'He who was killed was not an adulterer,' then the rebuttal of the charge is now the prosecutor's business, and he will produce the status." 22 This status, or point of "standing still," arises from the disagreement between prosecution and defendant about the circumstances of the murder and the kind of homicide that occurred.

Valla's coupling of manifestum with Quintilian's explanation of status theory anticipates the Elegantiae's second definition of certum as what is constitutum, an adjective that also recalls the terminology of this long-standing strategy of rhetorical invention. Even if Quintilian himself generally uses the Latin term status to denote the point of "standing still" or the issue of a forensic dispute, Cicero and the author of the Rhetorica ad Herennium both prefer constitutio. ${ }^{23}$ The Rhetorica ad Herennium, for example, uses constitutio to denote a "synthesis, a conjunction, co-stasis, or 'standing together' of specific statements, or declarations, between which there is an interval of conflict, or disagreement." ${ }^{24}$ And in his De inventione, Cicero notes that a constitutio is the "original clash, or primary conflict of causes." ${ }^{25}$ In one sense, this constitutio is a distillation of difference; in another sense, however, it also denotes a moment when parties push against each other or collide. The term with its now-familiar con- prefix suggests a meeting, but here a meeting of competitors or adversaries rather than of allies.

Taken together, Valla's marginal commentary at the Institutio's definition of certum and his own discussion of this word's meaning in the Elegantiae sketch a broad but consistent understanding of certainty. His earlier lexicographical discussion points to legal procedure and the "standing together" of status theory in anticipation of his later writings in the margins of Quintilian's text. There, Valla eschews the sensory understanding of certainty for one rooted in legal convention and consensus. Keeping in mind this notion of certainty as agreement, I now turn to Valla's attempts to reformulate dialectic and logic in his Dialecticae disputationes. Long understood to incorporate rhetorical

\footnotetext{
${ }^{22}$ Non fuit' inquit 'adulter': ergo depulsio incipit esse actoris, ille statum faciet, 3.6.17.

${ }^{23}$ In one discussion of status at 3.6.2, Quintilian explicitly notes his preference for the Latin term status over constitutio in discussions of locating the issue of a forensic dispute. The word constitutio appears only four times in the Institutio.

${ }^{24}$ Dieter, "Stasis," cited in n. 19 above, p. 359.

${ }^{25}$ See De Inventione 1.10 and Dieter, cited in n. 19 above, p. 364-365. For further references to constitutio as the "formulation of the point at issue in a case," see OLD 7a and TLL vol. IV 526, 65sqq.
} 
elements from Quintilian's manual, the Disputationes shows how Valla again understands certum through the lens of forensic argument and how-by situating this particular adjective at the center of his reform of modal logic-he leverages certainty in this effort to "rhetoricize" the technical methods of scholasticism.

\section{Legal Certainty in Valla's Humanist Dialectic}

Sometimes called the Repastinatio, a "retilling" of scholastic philosophy, Valla's Dialecticae disputationes aims to prune back the overgrown terminology of argumentation and proof. This work takes upon itself to redefine what practicing philosophy fundamentally means, but even if Valla's project in the Disputationes is more directly philosophical than that in the Elegantiae or in his commentary on the Institutio, he nevertheless illustrates his fondness for Quintilian throughout this work. ${ }^{26}$ Valla recommends that philosophy and dialectic look to his preferred model from antiquity to replace Aristotle and the methods proposed by his scholastic followers. In the work's first chapter, which brims with Aristotelian predicables and transcendentals, Valla asks himself, "in translating these terms, whom should I follow but Quintilian?"27 And Valla's insertion of Quintilian's thought into the Aristotelian system of logical argumentation was, in some sense, a literal one. In the second book of the Disputationes (2.21-23), Valla merely copies much of the second half of Book 5 of the Institutio word for word in lieu of a discussion or even paraphrase

\footnotetext{
${ }^{26}$ For a discussion of Valla's reorientation of the study of philosophy, see C. S. Celenza, "Lorenzo Valla and the Traditions and Transmissions of Philosophy," Journal of the History of Ideas 66:4 (2005): 483-506; and L. Nauta, "Lorenzo Valla and the Rise of Humanist Dialectic," in J. Hankins, ed., The Cambridge Companion to Renaissance Philosophy (Cambridge: Cambridge University Press, 2007) 193-210. For a specific example of Valla's efforts to use rhetorical strategies and sources to reformulate topics of scholastic theology, see C. E. Trinkaus, "Lorenzo Valla on the Problem of Speaking About the Trinity," Journal of the History of Ideas 57:1 (1996): 27-53. For a treatment of the Disputationes as "a classic example of negative dialectic [or] of a mode of writing and analysis which is focused not so much on constructing a new system as it is in dismantling an older one," see W. S. Blanchard, "The Negative Dialectic of Lorenzo Valla: A Study in the Pathology of Opposition," Renaissance Studies 14:2 (2000): 149-189.

${ }^{27}$ In quorum translatione quem potius quam Quintilianum sequar?, 1.1.6. Translations of Valla's Disputationes are adapted from Dialectical Disputations, ed. and trans. B. Copenhaver and L. Nauta (Cambridge, MA: Harvard University Press, 2012). Numbering of chapters and sections of Valla's Disputationes is taken from the same edition.
} 
of Quintilian's work. ${ }^{28} \mathrm{He}$ justifies this transplanting by appealing to Quintilian's unparalleled talents: "no one - unless God were 'someone,' so to speak-can say anything that has the mighty genius and eloquence of Quintilian's language.."29 This selection includes Quintilian's chapters on technical proof (De probatione artificiali, 5.8), signs (De signis, 5.9), and arguments (De argumentis, 5.10), the last of which includes his investigation of certum discussed earlier in this article.

In the Disputationes, however, Valla's interest in certum and its role in forensic argument extends well beyond these direct citations of the Institutio. Following Quintilian, in fact, Valla turns to the vocabulary of certainty in his definition of modal arguments in the second book of the Disputationes: "every proof is produced through truths that are certum, and through them, that very truth (veritas) causes some other truth (verum), which was incertum, to be seen as certum.." ${ }^{10}$ We immediately notice two key differences between Valla's definition of proof here and Quintilian's definition of the "nature of all arguments" in Book 5 of the Institutio. First, Valla concerns himself with the verum, not merely the certum, as it is revealed through argumentation. Whereas Quintilian writes that it "is the nature of all arguments that nothing is shown to be certain by what is uncertain," Valla here includes additional concerns for "the very truth" of arguments, concerns that appear to be absent from his ancient source. ${ }^{31}$ Second and more

${ }^{28}$ This selection includes Institutio 5.8 .1 to 5.10 .125 , a full thirty-one pages of Latin in the most recent I Tatti edition. The earliest editions of Valla's Disputationes were written before Valla's acquisition of Quintilian's text in 1443 and in fact already included these portions of the Institutio. The version of the Disputationes which Valla was still revising at the time of his death in 1457 serves as the basis of the latest edition from I Tatti (Copenhaver and Nauta, Dialectical Disputations, cited in n. 27 above, p. 2:498-499).

${ }^{29}$ neminem neque ea ingenii vi neque ea eloquentia posse quicquam dicere-nisi Deus aliquis, ut sic dicam, foret-qua Quintilianus dixit, 2.20.1-2.

${ }^{30}$ probatio omnis fit per vera quae certa sunt, facitque per haec ipsa veritas aliud quoddam verum videri certum quod erat incertum, 2.19.22. Alan Perreiah's recent study of Valla's approach to language asserts that "Valla conflates truth with certainty" (Renaissance Truths: Humanism, Scholasticism, and the Search for the Perfect Language (Burlington: Ashgate, 2014), 70). While these two terms are closely related, however, Valla does not fuse them entirely: as he shows here, what is verum can nevertheless remain incertum. For Valla there was likely not an important distinction between veritas and verum since "substantive nouns like 'falsity' and 'truth' do not have a different signification from their corresponding adjectives" (Nauta, In Defense of Common Sense, cited in $n$. 4 above, p. 67-68).

${ }^{31}$ Valla's understanding of truth continues to inspire scholarly debate. C. Trinkaus argues that for Valla "truth and knowledge are ... what an individual thinks they are" (The Scope of Renaissance Humanism (Ann Arbor: University of Michigan Press, 1983), 151). Peter Mack, taking an opposite view, argues that Valla understands that "language 
central to the present discussion, Valla omits any catalog of what qualifies as "certain" - a stark contrast with Quintilian's extensive list - and leaves his readers without an obvious definition of what this central term might even mean.

Before excavating Valla's understanding of certainty itself, we first investigate the reason for his interest in the verum. Underlying Valla's preoccupation with the truth is his dismantling of the tradition of Aristotelian modal propositions. Valla's critique of such modality is two-fold: first he criticizes the redundant and confusing terminology of the six traditional modal adjectives-possible, impossible, necessary, contingent, true, false-and second he challenges the category of modal propositions at its root by arguing that all sentences, and not only those of the six original varieties, are modal insofar as they are true. ${ }^{32}$ As Lodi Nauta explains, Valla "starts with criticizing the traditional six modal terms ... . [but] soon changes tactics and extends the range of 'modal' terms to include all kinds of qualifications of verbs such as 'easy/difficult,' 'certain/uncertain,' and 'useful/not useful.'"'33 After Valla first restricts the traditional range of modal statements from six to one (the true), he then expands the reach of true statements well beyond their original role and introduces "a whole new concept of modality, which comes close to an adverbial qualification." 34 In summary, Valla places all Aristotelian modes under the category of true statements and explains that a claim of what is possible or necessary or contingent nevertheless makes a truth claim about such possibility, necessity, or contingency.

Valla's emphasis on the truth of all kinds of modal propositions leads him to propose the radically true nature of all arguments more

adequately describes what is in the world [and that] truth depends on accurate knowledge of the world and correct representation of such knowledge" (Renaissance Argument: Valla and Agricola in the Traditions of Rhetoric and Dialectic (Leiden: Brill, 1993), 57). For a discussion of the "true" in the Disputationes, see Nauta, In Defense of Common Sense, cited in $n .4$ above, p. 67-70. See also a refutation of an alleged skepticism of the Disputationes in J. Monfasani, "Lorenzo Valla and Rudolph Agricola," Journal of the History of Philosophy 28 (1990): 181-200 (p. 192-198).

${ }^{32}$ For a helpful discussion of Valla's views on modality more generally, see Nauta, In Defense of Common Sense, cited in n. 4 above, p. 230-238, and Mack, Renaissance Argument, cited in n. 31 above, p. 90, where Mack calls Valla's treatment "very cavalier."

${ }^{33}$ Nauta, In Defense of Common Sense, cited in n. 4 above, p. 230.

${ }^{34}$ Nauta, In Defense of Common Sense, cited in n. 4 above, p. 232. Valla summarizes his new conception of modal logic in a defense against charges of heresy in his Defensio Quaestionum in Philosophia Laurentii Vallensis, Viri Doctissimi atque Eloquentissimi: Male dici propositiones 'modales' easque sex, cum sint proprie infinite, §7 (G. Zippel, L'autodifesa di Lorenzo Valla per il processo dell'inquisizione napoletana (1444) (Padova: Antenore, 1970), 86). 
generally: a proof (probatio), which is the aim of argument (argumentum), "ought to be true without qualification." ${ }^{\prime 35} \mathrm{He}$ ultimately concludes that every argument, and not just individual propositions, must employ true statements in all its parts:

In fact, all parts of an argument must be true, whether you say it is 'necessary' or 'possible' or 'easy' or 'honorable' or anything else. Suppose I say 'it is honorable that a citizen should fight for his country': will this sentence really come under any of those modes? Not at all. Because the case is very clear, let this one example suffice for many. Accordingly, I think that a 'modal' sentence means nothing, and that whatever weight those six modes have, the nouns or verbs that I have mentioned have just as much; but I think that necessity and possibility is in the conclusion, just as there is truth in all the parts of the structure of an argument. ${ }^{36}$

Valla cannot be clearer when he asserts that a modal statement "means nothing." Rather than hinge his understanding of modal arguments on careful analysis of possibility, contingency, or necessity, Valla instead considers only the truth of such proof. As he explains earlier in his text, "proof does not come from the false," and here he reiterates that "there is truth in all parts of the structure of an argument. ${ }^{\prime \prime 37}$

${ }^{35}$ quasi falsitas ad probationem faciat, quae vera utique debet esse, 2.19.4.

${ }^{36}$ Omnia enim sint vera oportet, sive dicas necesse est sive possibile sive facile sive honestum sive cetera omnia. Quid enim si dicam honestum est civem pugnare pro patria: nunquid sub aliquo illorum modorum haec erit enuntiatio? Minime. Unum pro multis in re apertissima suffecerit exemplum. Quapropter ita sentio nihil esse enuntiationem modalem, tantundemque momenti quantum illa sex habent, habere cetera quae dixi nomina seu verba; sed necessitatem ac possibilitatem in conclusione esse, sicut veritatem in omnibus partibus argumentationis, 2.19.7.

${ }^{37}$ For Valla's claim that proof does not arise from what is false (e falso non fit probatio), see Disputationes 2.19.4. Compare Quintilian's claim that things are sometimes proven by their opposites (12.1.35): plurima contrariis probantur. As Nauta explains, Valla "distinguished syllogisms with certain and true premises, leading to certain conclusions, from those syllogisms with premises that are not so certain, that is, half true and half certain (semivera ac semicerta)," pointing to a shades of probability or necessity in modal logic (In Defense of Common Sense, cited in n. 4 above, p. 233-234). These variations in probability and necessity, Nauta further argues, reflect the three degrees of credibility in Quintilian's own account of proof at 5.10.16-18, but neither Quintilian nor Valla provides a robust account of these variations. Quintilian writes that providing an explanation of these degrees of probability and necessity "is not so much a long task as an impossible, or rather infinite, one, and besides it is a matter of common human understanding" (non enim longum tantum, sed etiam inpossibile ac potius infinitum est, praeterea positum in communi omnium intellectu, 5.10.18). See also Mack, Renaissance Argument, cited in n. 31 above, p. 80-88, where Mack details some of peculiarities of Valla's notions of proof and argument. Mack notes "the appearance 
Where, then, should one insert certainty? If Valla commits to an understanding of argument where "every proof is produced through truths that are certum, and through them, that very truth (veritas) causes some other truth (verum), which was incertum, to be seen as certum," it seems paradoxical for him to advance this radical restructuring of modal propositions as truth claims. To clarify Valla's interest in certainty, we can look to a nearby account of argumentation in the Disputationes where Valla briefly explains the role of certainty in this model of proof:

In this context [of modal arguments], however, 'True' is the same as certum because it matters not at all that something is true unless it is certum atque confessum. But in the first two parts of a syllogism or structure of argument, a truth is posited as certum atque confessum as such. In the last part, however-in the conclusion-the truth is extracted by force (extorquetur), and thus it has necessity, or a sort of necessity. ${ }^{38}$

In this explanation of logical premises and their conclusions, Valla uses legal language to reformulate dialectical reasoning as a concern of the lawyer's courtroom rather than the philosopher's study, and more specifically, he shows again how he understands certainty as a concept centered around agreement, and particularly an agreement of a forensic orientation. The first two parts of an argument-that is, its two premises-are already confessa, and Valla's use of confiteor, a verb closely associated with the world of criminal action, imbues his description of the syllogism with an air of forensic strategy. ${ }^{39}$ Valla's legally tinged terminology here extends also to the third part of the argument-the conclusion-where the truth must be

of three different terms which may be thought to overlap to some extent: true, agreed and necessary" (p. 82).

${ }^{38}$ Idem autem est hoc loco verum quod certum, quia nihil attinet esse quid verum nisi fuerit certum atque confessum. Sed veritas duarum priorum syllogismi argumentationisque partium, pro certa atque confessa ponitur. In ultima autem-idest in conclusione-extorquetur, ideoque necessitas inest sive tanquam necessitas, 2.19.8. The most recent I Tatti translation renders nihil attinet esse quid verum as "nothing gets to be true." I choose to render attinet as an impersonal verb with an accusative and infinitive verb, as recommended at OLD attineo 7c. For a brief commentary on this passage, see Nauta, In Defense of Common Sense, cited in n. 4 above, p. 234.

${ }^{39}$ For the legal dimension of confiteor, see wide-ranging examples from Plautus and Terence through Statius and Tacitus at OLD 1a, 1c and TLL vol. IV 226, 55sqq. For examples of confessus as a synonym of manifestus, the word used as a synonym for certum in the Elegantiae, see TLL vol. IV 232, 44sqq. Nauta explains that certum atque confessum amounts to "an almost pragmatic definition of truth that, fully in line with the rhetorician's understanding of truth, had been formulated by Aristotle in his Rhetoric and restated by Cicero and Quintilian" (In Defense of Common Sense, cited in n. 4 above, p. 233). 
"extracted" (extorquetur), recalling the gathering of evidence "by forcible argument" or even by dislocating joints and torturing on the rack. ${ }^{40}$ Valla's use of extorqueo also recalls methods of gathering of evidence that Quintilian himself considers in his discussions of inartificial proofs: as Valla's model for his work, Quintilian describes how an expert interrogator can "extort (extorquere) from a witness what he did not want to say." 41 Our humanist reformer thus reinforces that rational arguments are dependent on the language of legal procedure, even in the context of philosophical dialectic. ${ }^{42}$

More fundamentally, the lexical composition of the word confessum reminds readers that certainty arises from interactions with others. The verb confiteri means not merely to fess up, but to confess. Its first lexical component, con-, suggests that certainty does not arise privately through meditation in one's library but rather through the admissions and acknowledgments that come about through adversarial questioning. To extract a confession, so the Disputationes implies, involves generating agreement with some other person, not merely with oneself. ${ }^{43}$ Like Valla's recollection of the consuetudo of Julianus and his coupling of certum and constitutum in the Elegantiae, this paradigm of argumentation in the Disputationes yet again reinforces the "togetherness" at the root of Valla's understanding of certainty and its usefulness for discovering truths. ${ }^{44}$

\footnotetext{
${ }^{40}$ See OLD extorqueo 2, 3 and TLL vol. V 2, 2043, 60sqq.

${ }^{41}$ At in eo qui verum invitus dicturus est, prima felicitas interrogantis extorquere quod is noluerit. ... Respondebit enim quae nocere causae non arbitrabitur, ex pluribus deinde quae confessus erit eo perducetur ut quod dicere non vult negare non possit, 5.7.17. Note, too, the appearance of confessus. See Quintilian's similar use of extorqueo at 5.7.27.

${ }^{42}$ Nauta also underscores the forensic nature of Valla's approach: "The orator may use syllogism, but since his task is to plead rather than to seek the truth, he must employ the full range of his verbal skills to attract and convince the jury and the audience, who often are ignorant of the fine points of dialectic" (In Defense of Common Sense, cited in n. 4 above, p. 235).

${ }^{43}$ Framing argumentation around agreements, perhaps to Valla's disappointment, might be traced to the view of dialectic in Aristotle, who explains that only scientific demonstration uses premises that are "primary and true" whereas dialectical argument uses endoxa, premises that are "reputable" and in many cases "agreed upon." See Topica 100a25-30 and 100b21-23. For a recent discussion of the role of endoxa in argument, see D. Frede, "The Endoxon Mystique: What Endoxa Are And What They Are Not," in B. Inwood, ed., Oxford Studies in Ancient Philosophy (Oxford: Oxford University Press, 2012), 185-214. Nauta also points to the legal underpinnings of Valla's explanation here (In Defense of Common Sense, cited in n. 4 above, p. 233).

${ }^{44}$ Valla's metaphor of argumentation as a forensic procedure aimed at forming consensus is perhaps at odds with a later military metaphor where Valla explains how "when two of us dispute with one another, we are not really enemies, as those
} 
The Disputationes, like the Elegantiae and the marginal commentary on the Institutio, shows again how Valla understands certainty through the forensic agreements that ground Quintilian's own account of certum. Not merely an explanation of an ancient rhetorical treatise or a clarification of its terminology, however, Valla's "retilling" of scholasticism shows how the humanist was eager to use Quintilian's notion of certainty in his own innovative writings on a reformed humanist dialectic or perhaps even a proto-"social epistemology." ${ }^{\prime 45}$ And as we shall see now, Valla's pervasive coupling of certum with the vocabulary of agreement—constitutum, consuetudo, consensus, confessum —adumbrates his reformulations of a variety of legal concepts including natural and conventional laws. Valla's jurisprudential writings, in fact, clarify the role of agreements in dialectic by showing how reason itself manifests in the consensus underpinning both ius gentium and ius naturale.

\section{The Humanist Law of Agreement}

As we have already seen in Valla's citation of Julianus in the margins of the Institutio, Valla was familiar with at least one ancient discussion of how laws can be derived from common practice or local conventions, whether enacted through consuetudo or dissolved through desuetudo. Just as Valla's commentary on Quintilian's text presents two sources for the law-a written statute or a community's "very acts and deeds"-his account of leges in the Elegantiae similarly points to the importance of popular support in grounding civil law:

Laws come from either a prince or a free people. Those which are established by a king do not require the consensus of one other person. There are those which are brought to the people and which are not really ratified without the people's decree, because the public is accustomed to being asked, or rather interrogated, about them. These laws are called rogationes. ${ }^{46}$

people are when they fight; both of us soldier under the same commander-the Truth" (non enim hostes inter nos sumus cum disputamus, ut illi cum pugnant; sed sub eodem imperatore-quae est Veritas—utrique militamus, 3.pr.1). On this metaphor, see Nauta, In Defense of Common Sense, cited in n. 4 above, p. 239.

${ }^{45}$ For an introductory account of the modern study of "social epistemology," in which "veritistic" group practices might be effective "from a truth-acquisitional point of view," see A. I. Goldman, "Social Epistemology," Crítica: Revista Hispanoamericana de Filosofía 31 (1999): 3-19.

${ }^{46}$ Sunt igitur leges aut principis, aut liberi populi. Quae a rege conduntur, alterius consensum non requirunt; quae ad populum feruntur, quaeque sine eius iussu fere ratae non sunt, quia rogari, id est, interrogari de his populus solet, rogationes etiam dicuntur, 4.48. 
Valla's capacious understanding of leges here includes not only laws that are imposed upon the population by a ruler (a rege), but also those which are validated by the people's agreement. At one extreme, a law enacted by an autocrat requires no consensus, not even of "one other person." At the other extreme, however, laws that are enacted through a rogatio "are not really ratified without the people's decree.." ${ }^{\prime 77}$ Valla's citation of Julianus and his brief commentary on leges in the Elegantiae here anticipate a more robust defense of consensus-based laws in his extensive commentary on Quintilian's text. In those annotations, Valla rejects natural law (ius naturale) in favor of laws grounded in broad agreements, and he lays out a theory of laws rooted in the conventions of certainty, demonstrating yet again his adoption of Quintilian's notion of certum as agreement and reinforcing a view of reasoning itself as a process of generating consensus.

In the second book of the Institutio, Quintilian suggests that there are three categories of law: the sacred, the public, and the private. ${ }^{48}$ In his marginal commentary on this passage, Valla first notes the superiority of Quintilian's formulation to that found in the Digest-Melior hec divisio quam est illa in Digestis-and then includes a long citation from the jurist Ulpian, a defender of ius naturale, as a foil for Quintilian's view. ${ }^{49}$ Of great interest to Valla is Ulpian's distinction between natural law (ius naturale) and the law of nations (ius gentium), a separation that Ulpian explains as follows:

Natural law (ius naturale) is what nature has taught to all animals. For that kind of law is not only the property of the human race, but of all

\footnotetext{
${ }^{47}$ The final clause of Valla's explanation references the rogatio, a legislative procedure dating to the Roman Republic that involved a Roman magistrate proposing legislation as a question to a Roman assembly. After the requisite period of three days reserved for debate (trinundium), the assembly would reconvene to answer the question with a 'yes' or 'no,' either passing or rejecting the law (OCD lex).

${ }^{48}$ nam et genera sunt tria sacri, publici, privati iuris, 2.4.33. Cesarini Martinelli and Perosa call Valla's notes on this section of the Institutio the "pearl" of the entire manuscript (Le Postille all'"Institutio Oratoria" di Quintiliano, cited in n. 5 above, p. 1xxxii).

${ }^{49}$ Ulpian writes that there are only two kinds of law, the public and the private, where public law is further divided into laws pertaining to sacred rites (in sacris), those pertaining to priests (in sacerdotibus), and those pertaining to civil officers (in magistratibus). Ulpian similarly divides private laws into three categories: natural laws (ex naturalibus praeceptis), laws of different nations (ex praeceptis gentium), and civil laws (ex praeceptis civilibus): Huius studii due sunt positiones, publica et privata. Publicum ius est quod statum rei publice Romane spectat, privatum quod ad singulorum utilitatem: sunt enim quedam publice utilia, quedam privatim. Publicum ius in sacris, in sacerdotibus, in magistratibus consistit. Privatum ius tripartitum est: collectum enim est ex naturalibus preceptis aut gentium aut civilibus, at Institutio 2.4.33 (Cesarini Martinelli and Perosa, Le Postille all'"Institutio Oratoria" di Quintiliano, cited in n. 5 above, p. 56-57).
} 
animals, including those born both on land and in the sea. And it is shared with birds, too. The joining of male and female derives from this law, which we ourselves call matrimony. And the procreation of children comes from this law. Indeed, we see that other animals, even wild animals, have experience with this kind of law. The law of nations (ius gentium) is that which human nations use. And one is allowed to understand that the law of nations is separate from natural law since the latter pertains to all animals, whereas the law of nations is common only among men. ${ }^{50}$

In a pointed critique of Ulpian's separation of ius naturale and ius gentium, Valla rejects the notion that law can ever be natural, arguing that the existence of any law among "beasts" is even more absurd than Ulpian's claim that the law of nations is a kind of private law. ${ }^{51}$ In contrast to Ulpian's description of ius naturale as a law that pertains to all living creatures and their mating and procreation, Valla defines law as a uniquely human institution: "nature is one thing, and the law is another, and whatever animals do, undoubtedly they do through nature." ${ }^{12}$

\footnotetext{
${ }^{50}$ Ius naturale est, quod natura omnia animalia docuit. Nam ius istud non solum humani generis proprium est, sed omnium animalium, que in terra, que in mari nascuntur; aviumquoque commune est. Hinc descendit maris et femine coniugatio, quam nos matrimonium appellamus; hinc liberorum procreatio; videmus enim cetera animalia, feras etiam, istius iurus [peritia] censeri. Ius gentium est quo gentes humane utuntur. Quod a naturali recedere facile intellegere licet, quia illud omnibus animalibus, hoc solis hominibus inter se commune sit, at Institutio 1.4.33 (Cesarini Martinelli and Perosa, Le Postille all'"Institutio Oratoria" di Quintiliano, cited in n. 5 above, p. 57). Valla's manuscript uses the noun peritia (practical knowledge or skill) instead of the adjective perita (skilled or expert), but I have emended the text to use the predicate adjective after censeri in agreement with animalia. The noun peritia would effect the sense of animals being considered a skill itself rather than skillful.

${ }^{51}$ Nam quod bestias etiam complexus est, ut dicat "ius naturale," hoc absurdius est quam id quod modo peccavit, at Institutio 2.4.33 (Cesarini Martinelli and Perosa, Le Postille all "Institutio Oratoria" di Quintiliano, cited in n. 5 above, p. 57-58).

${ }^{52}$ Aliud est enim natura, aliud ius, et quicquid animalia faciunt, haud dubie natura faciunt, at Institutio 2.4.33 (Cesarini Martinelli and Perosa, Le Postille all' Institutio Oratoria" di Quintiliano, cited in n. 5 above, p. 58). In this edition's introduction, Martinelli postulates that this difference hinges on Valla's understanding of choice as a uniquely human capability: "The concept of justice, which involves the freedom of choice, is proper only to mankind. And animals defend themselves from violence, but "whatever happens justly or unjustly pertains only to men'" (p. 1xxxiii). Valla emphasizes his distaste for the term ius naturale in the Elegantiae, too, by drawing contrasts between the behavior of men and the behavior of animals. In a chapter titled Aliud leges esse, aliud iura, he explains that "it is ridiculous to speak of ius naturale, which nature teaches to all animals. An instinctive desire to mate and even for harming, plundering, and killing a weaker animal-who says this is ius? And so Cicero in his books on duties was silent about the natural law, illustrating that there is ius only among humans, and that is the ius gentium or the ius civilium" (Nam ius naturale dicere,
} 
Valla's emphatic separation of law and nature here sets the stage for a notion of conventional or positive law, and in his continued criticism of Ulpian, Valla insists that laws arise from human agreements rather than any natural guidelines that exist independent of human activity. Valla illustrates his interest in such agreements by appealing to a perplexing requirement of consistency among all iura whereby a nation should not be able to enact a ius gentium that contradicts the putative ius naturale. By adopting Ulpian's notion of natural law, so Valla insists, such contradictions would appear:

That which all nations consider just-since nature is their guide-and about which one nation does not differ from another, let us call that one kind of law. And that which nations or peoples individually have deemed to be just on their own, let us call that another kind, at least regarding its appearance. For if it were the case, as Ulpian says, that all men are born free by natural law but become slaves by the law of nations, it would not be called the law of nations but rather injustice (iniuria). And this would likewise be the case if some nation wished to have a law for taking a cow as a wife: because if this law of marrying a cow is the ius, then that first notion of a ius naturale is not ius at all. Indeed, it is not possible for the law to be contrary to the law (neque enim potest ius iuri esse contrarium). ${ }^{53}$

Valla views iura as a single set of rules that must be internally consistent-"it is not possible for the law to be contrary to the law"but he then illustrates the contradictions in contemporary thought concerning slavery: men are born free according to natural law, but through the law of nations, they are made slaves. ${ }^{54}$ To strengthen his case, Valla then invokes a derisive hypothetical scenario: that a nation, against the principles of Ulpian's alleged ius naturale, might sanction

quod natura omnia animalia docuit, ridiculum est. Appetitum coeundi atque adeo nocendi imbecilliori animali, spoliandi, occidendi, quis ius esse dixerit? Ideoque M. Tullius in libris officiorum de iure naturali silentium egit inter solos homines ius esse significans, idque Gentium esse vel Civilium, 4.48).

${ }^{53} \mathrm{Quod}$ enim omnes gentes iustum sentiunt natura duce, nec alia ab alia differunt, id unum genus iuris existimememus, alterum, huius nimirum speciem, quod singule gentes populive privatim iustum esse decreverunt. Nam quod ait Ulpianus, omnes nasci liberos naturali iure, sed iure gentium servos fieri, si ita esset, non ius gentium, sed iniuria appellabitur, perinde ac si vellet aliqua gens ius esse vaccam ducendi uxorem; quod si hoc ius est, illud ius non erit: neque enim potest ius iuri esse contrarium, at Institutio 2.4.33 (Cesarini Martinelli and Perosa, Le Postille all' "Institutio Oratoria" di Quintiliano, cited in n. 5 above, p. 58)

${ }^{54}$ Valla calls this contradiction between the two laws iniuria, often translated as "injustice" as I have done here. One might also think of the term as what contradicts ius, an "unlawfulness" or even "anti-lawfulness." 
human-bovine matrimony ${ }^{55}$ Remaining committed to the axiom that one ius cannot contradict another, Valla rejects a ius naturale that might run counter to the agreements and conventions of any particular jurisdiction, and whatever "nations or peoples (gentes populive) individually have deemed just on their own" must stand as a kind of ius on equal footing with natural law. Rather than define two independent sets of law or define some method of adjudicating conflicts between positive and natural laws, Valla instead insists on "nations or peoples" as the source of legal authority, and since the notion of ius naturale runs counter to this authority, Valla rejects it entirely.

Valla's detailed critique of Ulpian's natural law serves as a prelude to his central jurisprudential claim found in his comments alongside Book 2 of the Institutio, a claim which itself is taken from another passage of Quintilian: "all justice rests either upon nature or upon convention (natura vel constitutione)." ${ }^{\prime 56}$ At first glance, it seems counterproductive for Valla to appeal to Quintilian's principle, for this ancient maxim unambiguously cites natura as a foundation for justice, and Valla has just excoriated Ulpian's theory of a ius naturale. Valla's understanding of the law rooted in nature or convention, however, seems to understand the word "or" (vel) with only a weakly disjunctive force: laws must be rooted in either nature or convention, and in all likelihood in some combination of the two. Turning once more to the Elegantiae, we find that Valla's conception of natura, in fact, is not identified with an abstract ius naturale but instead is coupled with

\footnotetext{
${ }^{55}$ Immediately following his principle of non-contradiction among iura, Valla comments briefly on Quintilian's third category of laws, sacred law: "natural law, if it differs from the law of nations, can be called the divine law or sacred law" (cum presertim ius naturale, si quid a gentium differt, possit appellari ius divinum aut ius sacrum). His discussion of sacred law is unclear, and Martinelli and Perosa note that Valla may simply use ius divinum as another phrase for ius naturale, as he seems to do in his commentary on Institutio 2.4.33 (Le Postille all' Institutio Oratoria" di Quintiliano, cited in n. 5 above, p. 1xxxiv). There is a similar kinship between ius divinum and ius naturale in the Elegantiae, for in his discussion concerning leges and ius, Valla writes that Cicero "nevertheless referred to the ius naturale in his rhetorical works, but that which pertains only to mankind; he meant that there were six kinds of this law: religio, pietas, gratia, vindicatio, observantia, veritas" (In rhetoricis tamen ius naturale statuit, sed quod in homines tantummodo cadat; cuius species sex esse voluit, religionem, pietatem, gratiam, vindicationem, observantiam, veritatem, 4.48). For a more thorough discussion of the inconsistencies in Valla's use of ius divinum, see Cesarini Martinelli and Perosa, Le Postille all' Institutio Oratoria" di Quintiliano, cited in n. 5 above, p. lxxxiii-lxxxvi.

${ }^{56}$ iustum omne continetur natura vel constitutione, 7.4.5. Valla cites this passage from the Institutio as part of his commentary of the Institutio at 2.4.33 (Cesarini Martinelli and Perosa, Le Postille all' "Institutio Oratoria" di Quintiliano, cited in n. 5 above, p. 58); however, he does not comment on this passage of the Institutio where it appears in Book 7.
} 
human agreements, a coupling he expresses in a long chain of verbal phrases:

That which was established through the custom of ancestors was thus established through laws and was settled through laws (legibus ita constitutum est). And that was thus established through nature, and was thus settled through nature (ita natura constitutum est), and was thus prescribed by nature (ita natura praescriptum). And that thing which nature herself prescribed to us, it was given to us through nature, just as we give aid to those who are in danger. Reason itself (ratio ipsa) commands this to us, and it thus seems that reason dictates it. ${ }^{57}$

Cumbersome though they may be, these clauses show how customs and laws can themselves be "settled through nature" (natura constitutum est), a brief phrase that intertwines the conventional and natural dimensions of law, the ius naturale and ius gentium. Underlying Valla's rendering here of natura, moreover, is ratio, the rational faculty that guides not just nature but even mankind's formation of its own laws and customs. In other words, Valla understands that what is constitutum within human society is a manifestation of natura's effects in reasoned human activity. These customs and agreements, so Valla argues here, are not legal instruments counter to or even independent of nature's dictates.

Valla reiterates his understanding of the natural, rational basis of law and its close ties with human legal agreements in his commentary on the Institutio, where he writes that conventional laws are natural insofar as they stem from the reason common to all men: "what natural reason (naturalis ratio) has established (constituit) among all people is rightly preserved and called the ius gentium among all nations, since it is the law which all nations use. ${ }^{158}$ By orienting the ius gentium around a universally shared natural reason (gentes omnes utuntur), Valla blurs the distinction between natural law and the law of nations. Natural laws, at least as Valla understands them, do not descend from heaven but rather arise from humanity. For the purposes of the present study, too, this intertwining of natural and positive law illustrates yet again Valla's blending of rational and rhetorical concepts through

${ }^{57}$ More maiorum comparatum est, legibus ita comparatum est, legibus ita constitutum est, ita natura comparatum est, ita natura constitutum est, ita natura praescriptum, hoc nobis ipsa natura praescribit, nobis natura datum est, ut periclitantes allevemus. hoc ratio ipsa praescribit, ita videtur ratio dictare, 3.78 (3.89 in Garin).

${ }^{58} \mathrm{Quod}$ autem naturalis ratio inter omnes homines constituit, id apud omnes gentes pereque custoditur vocaturque ius gentium, cum quo iure gentes omnes utuntur (Cesarini Martinelli and Perosa, Le Postille all" Institutio Oratoria" di Quintiliano, cited in n. 5 above, p. 59). 
now-familiar terminology. Valla's use of constituit in his explanation of the essence and origin of the ius gentium recalls the several words throughout his discussion of certainty that rely on the same Latin prefix to denote various agreements: consuetudo, confessum, consensus. Just as Valla readily combines conventional laws with the naturalis ratio in jurisprudence, his refashioning of dialectic in the Disputationes combines the logical cogency of syllogistic forms and rhetorical elements of persuasion and shared belief. These discussions of jurisprudence, then, bolster our understanding of Valla's program of "rhetoricization" in the Disputationes by calling our attention once more to his careful use of the vocabulary of agreements even in discussions of natural reason.

\section{CONClusion}

It bears repeating that Valla's reliance on rhetorical texts in general and Quintilian's text in particular is not a novel claim in the study of this Italian humanist. What the present investigation clarifies is the influence of Quintilian's text in Valla's understanding of certainty and how this particularly forensic orientation of certum and related vocabulary persists throughout his many works. ${ }^{59}$ By pairing ratio with forms of the verb constituo throughout his legal discussions and by positioning certainty centrally in his reformed conception of modal logic, Valla's works coherently and consistently apply the terminology of certainty he provides in his Elegantiae. In that lexicographical treatment, where Valla suggests not just that one should turn to Quintilian to understand this concept but more particularly that one should refer to Quintilian's discussion of status theory, we find Valla's most explicit connections between certum and the rhetorical concerns surrounding consensus. By eschewing Quintilian's most explicit discussion of certum in Book 5 and instead pointing his readers to Book 3, Valla suggests that the concept of certainty is most closely associated with those ancient inventional questions of forensic oratory: an sit? quid sit? quale sit? ${ }^{60}$

\footnotetext{
${ }^{59}$ Nauta briefly mentions Valla's awareness of Quintilian's discussion of certum in the Institutio in his study of the Disputationes (In Defense of Common Sense, cited in n. 4 above, p. 234). I have shown that Valla's use of Quintilian's notion of certainty extends throughout several of his writings and that Valla's association of certum with a number of other words denoting agreement persists in these various works.

${ }^{60}$ For status theory considered as a "doctrine of inquiry" around these three questions, see M. Carter, "Stasis and Kairos: Principles of Social Construction in Classical Rhetoric," Rhetoric Review 7:1 (1988): 97-112.
} 
In fact, Valla's lexicographical investigation implies what is stated explicitly in the Disputationes, where Valla relies on his understanding of certainty to repackage the strategies and language of status theoryoriginally fit for the law courts-for use in dialectical argument ${ }^{61}$ :

Every proof is produced through truths that are certum, and, through them, that very truth causes some other truth, which was incertum, to be seen as certum, and this happens either necessarily or plausibly. There are, however, three ways for a truth to be incertum since, according to some of the greatest authorities, our doubts are of three kinds: whether something is; what that something or anything is; and what it is like. ${ }^{62}$

Valla's close integration of the syllogism and status theory reformulates dialectic in terms of the agreements and disagreements of forensic rhetoric, and his understanding of what is incertum as what is unsettled shows how disputes, both dialectical and rhetorical, can be categorized according to the three "doubts" in traditional renderings of status theory. The goal of argumentation, then, is to resolve disagreements about what is doubtful, and by using what is already certum atque confessum, proof tries to make certum a true but controversial or doubtful conclusion. Certainty, therefore, occupies a central role in both the beginning and the end of logical arguments: in the collection of premises that are agreed upon and finally in the resolution of disagreements in the argument's conclusion, a conclusion that eventually becomes confessum, constitutum, and certum.

Valla's project is simultaneously one of simplification as well as one of audacious broadening. He discards complex Aristotelian terminology and paradigms in favor of a simpler triad of questions, but as Valla closes his discussion of modal logic, he notes that status theory should be applied not merely to forensic disputes and philosophical proofs but also to matters from a wide variety of intellectual disciplines. He argues that "every problem-whether within the law or outside the law, whether within philosophy or outside philosophyderives from these questions. ${ }^{\prime 63}$ It should therefore not surprise us that

\footnotetext{
${ }^{61}$ Nauta makes note of the appearance of status theory in the Disputationes and Valla's debt to Quintilian in his understanding of this ancient framework (In Defense of Common Sense, cited in n. 4 above, p. 235-236).

${ }^{62}$ Probatio omnis fit per vera quae certa sunt, facitque per haec ipsa veritas aliud quoddam verum videri certum quod erat incertum, idque vel necessario vel verisimiliter. Est autem verum incertum triplici via quia, ut maximis quibusdam auctoribus placuit, tripliciter dubitamus: aut an quippiam sit; aut quid illud quippiam sive aliquid sit; aut quale sit ipsum aliquid, 2.19.22.

${ }^{63}$ ex quibus omnis quaestio-sive in iure sive extra ius, sive in philosophia sive extra philosophiam-pendet, 2.19.24.
} 
this terminology of certainty extends well beyond Valla's technical discussions of scholasticism. In fact, Valla defends this expansive approach by appealing once more to the lessons of his favorite Roman model, Quintilian. He concludes that "in each kind of inquiry-rational, moral, natural, and many others-our practice is to ask whether it is, what it is, and what it is like, which is almost explicit in the words of Quintilian." ${ }^{\prime 64}$ For Valla, then, Quintilian is the prime inspiration for turning philosophy and legal theory (and indeed any branch of intellectual activity) into a forensic investigation centered around status theory, a framework that takes the certainty of consensus as both its material and its aim.

\footnotetext{
${ }^{64}$ praeterea in singulis—rationali, morali, naturali, et sique sint alia-quaerere solemus an sit, quid sit, quale sit, ut propemodum ex Quintiliani verbis palam est, 2.19.25. In support of this expansive understanding of status theory, Valla cites Boethius on the unity of rational, moral, and natural investigations: omnis quaestio vel ex ratione disserendi vel ex naturali vel ex morali trahitur speculatione (De topicis differentiis 1.5.50, Patrologia Latina 64:1180A). Regarding this wide application of status theory, Quintilian himself takes inspiration from Cicero: "Most writers offer us three general issues. Cicero adopts these in the Orator, and thinks they embrace everything which comes into dispute or contention. They are: Does it exist? What is it? What sort of thing is it?" (a plurimis tres sunt facti generales status, quibus et Cicero in Oratore utitur et omnia quae aut in controversiam aut in contentionem veniant contineri putat: sitne, quid sit, quale sit, 3.6.44).
} 